Journal of Qualitative Criminal Justice \& Criminology

\title{
An Exploratory Examination of a Prison Disciplinary Process: Assessing Staff and Prisoner' Perceptions of Fairness
}

Ann Marie Rocheleau ${ }^{1}$

${ }^{1}$ Stonehill College

Published on: Apr 01, 2014

DOI: $10.21428 / 88 \mathrm{de} 04 \mathrm{a} 1.037 \mathrm{cb} 4 \mathrm{c} 4$

License: Creative Commons Attribution 4.0 International License (CC-BY 4.0). 


\section{ABSTRACT}

There has been scant research on how prison disciplinary processes work in comparison to the myriad of studies on individual, situational, and prison-level factors associated with prison misbehavior. This exploratory research delved into staff and prisoners' perceptions of a prison system's disciplinary process. Using in-depth interviews with 25 staff and 25 prisoners as well as direct observation of classification and disciplinary hearings, this research primarily focused on perceptions of fairness. It uncovered those features of the disciplinary process that prisoners and some staff assessed as problematic and unfair. These included: the nature, consistency, and investigation of disciplinary reports, the use of confidential informants, the staffing of disciplinary boards, the use of segregation time for non-serious offenses, and the long-term segregation of some offenders. Ideas for future research were explored and prison administrators were encouraged to focus on fairness as a key component to containing prison violence and serious misbehavior.

\section{Introduction}

In the 1974 landmark case Wolff $v$. McDonnell, 1 the U.S. Supreme Court determined that due process was lacking in the Nebraska prison disciplinary system. The prisoner, Robert McDonell, asserted that his loss of good time for a serious prison infraction violated his right to due process. The Supreme Court ruled that since his loss of good time affected his sentence length, his liberty was indeed at stake, and that he should have been afforded the following elements of due process:

1. "written notification of the charges at least 24 hours before the hearing, describing specific conduct upon which charges are based

2. the right to call witnesses and present documentary evidence

3. an impartial tribunal for hearing

4. a finding of guilt must contain a summary of the evidence relied upon, a specific statement of the reasons for the finding of guilt" (McShane, 2008, p. 139).

These elements of due process have generally been extended to other sanctions that result in the loss of liberty (e.g., segregation). However, these safeguards do not include the right to an attorney in disciplinary hearings or the right to cross-examine witnesses, nor do they include specifics about how prison systems should implement these safeguards.

In the decade after the Wolff ruling, legal scholars evaluated prison systems' implementation of these safeguards and found mixed results (Babcock, 1980; Fleming, 1981; Jones \& Rhine, 1985). For example, Babcock (1980) conducted a review of case law subsequent to Wolff and surveyed the disciplinary guidelines from 40 states, the District of Columbia, and the Federal Bureau of Prisons. He concluded that while definite progress had been made in some aspects of the disciplinary process, other 
safeguards were less likely to have been fully implemented. Most prisons had succeeded in implementing a formal appeals process and many states provided prisoners with either a prisoner or staff representative to help them prepare a defense and support them during the disciplinary hearing. However, he found continued deficits in the impartial make-up of the disciplinary board, access to witnesses, the exclusion of informants in the hearing process, and the reliance on written reports with little or no corroboration for a guilty finding. Little has been written about this topic in the last two decades.

In addition to the legal research on the implementation of Wolff in prison disciplinary processes, there has also been a great deal written more recently about mentally ill offenders who are involved in prison misbehavior and are sanctioned to segregation in disciplinary proceedings (Adams \& Ferrandino, 2008; Arrigo, Bersot, \& Sellers, 2011; Fellner, 2006). Criminologists have focused on the tensions between the needs of the mentally ill and the control mechanisms existing in prisons especially as they pertain to participation in the disciplinary process and the often resultant placement in segregation or even supermax prisons or units. Fellner critiqued the treatment of the mentally ill during disciplinary proceedings:

They typically do not recognize incompetence to participate in the proceedings ... Nor do disciplinary hearings permit an insanity defense, which would excuse a prisoner from guilt for conduct that he could neither appreciate nor control. Hearing officers may not even take mental illness into account as a mitigating factor in determining a sentence. They do not consider whether the prisoner's conduct reflected significant cognitive or volitional impairments. $(2006,41)$

It is no surprise then that mentally ill prisoners often find themselves headed to segregation after participation in disciplinary proceedings. Though courts in California and Wisconsin have ruled that prisoners with mental illness should be excluded from placement in long-term segregation or supermax facilities, $\underline{2}$ the practice still continues in many states (Arrigo et al., 2011).

Apart from the focus on due process rights and the plight of the mentally ill in the disciplinary proceedings, little research has been conducted on the disciplinary process itself (Flanagan, 1982; Howard, Winfree, Mays, Stohr, \& Clason, 1994; Reisig \& Mesko, 2009; Steinke, 2001). Prison disciplinary processes include the formal or informal response of correctional officers and other staff to prisoners' misbehavior, the disciplinary hearings where guilt is determined and sanctions are applied, and the appeals process. Taken together, these processes have enormous consequences both for individual prisoners and prison systems alike and can result in sanctions for the prisoners that range from the revocation of privileges (e.g., visits, use of the phone, loss of personal items) to extended periods in segregation along with the loss of good time. For prison systems, disciplinary processes are supposed to ensure the incapacitation of dangerous prisoners as well as both specific and general deterrence of future prison misconduct with the hope of preventing future staff and 
prisoner injury and death. Lovell and Jemelka (1996) estimated that each individual prison infraction at a medium-security prison in Washington state costs $\$ 970$ and that the total costs of disciplinary infractions for the state prison system is $\$ 9$ million per year. Despite high-stakes consequences of prison disciplinary processes (costs, increases in length of stay, transfer to a supermax facility, continued violence), there is a paucity of research, especially in comparison to the extensive research on the causes and correlates of prison misconduct and violence.

In his treatise on prison violence, Bottoms (1999) created a "speculative and interactive model" for maintaining good order and good behavior in prison (p. 258). His model included eight factors: population characteristics; prisoner involvement in treatment and education; the optimal level of physical restraint adopted by the prison; staff deployment, skills, and approaches; the use of power and routines as structural constraints; incentives and disincentives; the effects of situational events that might shape the level of violence in any given prison; and legitimation. One factor, legitimation, is relevant to the study of prison processes in general, but also to prison disciplinary processes in particular. Bottoms explained that its "core issue is whether, judged by the reasonable standards of the wider community in which the prison is set, prisoners come to see the behavior of their custodians as being justifiable, comprehensible, consistent and hence fair-or, alternatively, unwarranted, arbitrary, capricious, and overweening" (1999, p. 254). Bottoms acknowledged the three dimensions of legitimation that Ahmed ${ }^{3}$ discovered in his study of fairness in prison: fairness of staff; fairness of regime (operational aspects of the prison such as the amount of property, phone calls, and recreation time allowed); and distributive fairness based on prisoner perceptions of formal grievance and disciplinary processes (1999, p. 257). Fairness of staff and distributive fairness are both relevant to the study of prison disciplinary systems. They are related to both the concepts of procedural justice and defiance theory, which will be discussed in a later section.

Little is known about prison disciplinary processes and how they are perceived by staff and prisoners alike. As an exploratory off shoot of a larger study on coping and serious misconduct, $\underline{4}$ this study explored staff and prisoner perceptions of the disciplinary process in the Rhode Island Department of Correction. In-depth interviews were conducted with 25 staff and 25 prisoners involved in serious misconduct and violence. There were also direct observations of classification and disciplinary hearings. This study deconstructed the overall prison disciplinary process and examined each phase including the issuance of disciplinary reports, the disciplinary board, and sanctions received. The research focused mainly on perceptions of fairness.

\section{Review of the literature}

\section{Research on the prison disciplinary process}

There is a dearth of research on the actual prison disciplinary process. Some investigations have focused on correction officer discretionary decision-making in formally charging prisoners with 
disciplinary reports in the face of misbehavior (Bottoms, 1999; Hewitt, Poole, \& Regoli, 1984; McCorkle, 1992). However, reported incidents of misconduct and violence resulting in disciplinary reports represented only a fraction of actual misconduct and violence in prisons. Bottoms discussed two filtering points in the reporting of prisoner misconduct: prisoners who refrained from reporting most victimization, and correctional staff who may or may not have officially documented prisoner misconduct. Hewitt et al. (1984) discovered that even though correctional officers knew of more prisoner misconduct than was officially documented, they hesitated to report it in order to maintain the stable and positive climate preferred by the prison administration. In their description of the disciplinary process leading to lock-up in a segregation unit, Rocheleau, Forcier, and Jackson (1998) discussed the various discretionary decision points in which prison staff might decide to deal with the misconduct informally. These included the decision for prison staff to write a disciplinary report; the decision by prison supervisors to have the incident remain in the formal disciplinary process; and the disciplinary hearing where the report can be dismissed or the prisoner found guilty or innocent. Research on discretionary decision-making in the issuance of disciplinary reports has revealed staff bias against young offenders, minorities, drug abusers, and others (Poole \& Regoli, 1980).

Similarly, researchers studying prison infraction dispositions discovered that not only the seriousness of the infraction, but also the prisoner's age, marital status, and history of prior disciplinary infractions affected the outcome (Flanagan, 1982). Another similar study found that the security level of the prison was related to disposition, as well as seriousness of the infraction (Howard, et al., 1994). One research study that focused on the hearing process itself reported that prisoners who gave accounts and justifications of the circumstances of their misconduct events at disciplinary hearings were more likely to have their sanctions increased, rather than mitigated as intended (Steinke, 2001). Each of these studies used mostly quantitative research methods to examine an aspect of the prison disciplinary process.

\section{Legitimation, procedural justice, and defiance}

Perceptions of staff and distributive fairness are two dimensions of legitimation that are associated with prison disciplinary processes, and both of these concepts can also be linked to the concept of procedural justice. In 1990, Tyler studied Chicago citizens' encounters with police and courts and reported that people were more often concerned with whether the process of justice was fair than about the actual outcomes. As Paternoster, Brame, Bachman, and Sherman (1997) explained it, "An important implication of the procedural justice literature therefore, is that compliance may depend as much or more on the procedural fairness of sanction delivery as it does on the characteristics of the sanction imposed (i.e., its certainty and severity)" (1997, p. 166). Although one might assume that fair procedures would yield positive outcomes, research notes that procedural justice matters regardless of whether the outcome was positive or negative. Paternoster et al. delineated six components of procedural justice: representation, consistency, impartiality, accuracy, correctability, and ethicality (1997, pp.167- 
168). Representation is being allowed to tell one's story. Giving voice makes people feel their views are valued and listened to, they are more likely to view authorities positively, and in turn to be more likely to comply. Consistency in decision-making refers to similar treatment of different people and similar treatment of people over time. Paternoster et al. explained that people whose experiences are rated as equal to others will view those in authority as moral and legitimate and will be more likely to comply with rules in the future. Impartiality involves not allowing one's biases to affect the outcome of a decision. Accuracy refers to making the correct decision, in a public forum, based on reliable and valid information. Correctability is the ability to appeal a finding to a higher authority. The final component of procedural fairness is ethicality. Paternoster et al. explained that when authorities treat citizens with respect and dignity, they were acting ethically. They further concluded that "(r)espectful treatment by legal authorities is seen to be directly related to perceptions that authorities are moral, legitimate, and are deserving of compliance" (Paternoster et al., 1997).

Reisig and Mesko (2009) conducted a study on procedural justice and prison misconduct; there were structured interviews with 103 Slovene prisoners who were asked to self-report their misconduct. After the authors collected official disciplinary data, they discovered that procedural justice judgments by prisoners were directly associated with prisoner misconduct. The procedural justice scale was the only variable of over half a dozen that significantly predicted both self-reported and official misconduct. Sherman's associated concept of defiance theory (1993) demonstrates why this is so. He identified four concepts that were associated with people's responses to punishment, including legitimacy of the sanctioning agents; strength of the social bond between those being sanctioned and the sanctioning agent; shame; and pride. He argued that offenders will be defiant when they experience punishment as illegitimate, when they have weak bonds with those handing out the punishment, and in turn deny their shame, and instead focus on defiant pride. Paternoster et al. (1997). concluded that compliance is more likely to occur when those in authority impose sanctions in a fair manner, and when they do so while "still honoring and respecting the dignity of offenders" (p. 193).

The current research delineated the various steps in the disciplinary process in the Rhode Island Department of Correction. Through in-depth interviews, it examined staff members' and prisoners' general perceptions of the disciplinary process. Specifically, it focused on prisoners' perceptions of fairness and the concomitant issues of legitimation and procedural justice.

\section{The current study}

The issuance of disciplinary reports (called bookings in Rhode Island), the disciplinary process, and the sanctions allowed are governed by the Rhode Island Department of Corrections (RIDOC) Policy on Code of Inmate Discipline (2009). This policy had undergone a review and major revision by administrators in 2008 in order to afford staff more flexibility in their issuance of bookings and to increase the deterrent effect of the disciplinary and sanctioning process. Changes became effective in March 2009 
and included re-categorizing bookings into four classes, assigning a range of sanctions to each offense category, increasing the amount of possible time in segregation from 60 days to one year, and making changes to the disciplinary and appeal processes to assure accountability and standardization across facilities. The latter involved changing the make-up of the disciplinary board from three voting members (lieutenant chairing disciplinary board, correctional counselor, and correction officer) to one voting member. While the counselor and officer could still be present, the lieutenant running the board was given full discretion to make decisions.

Officers can choose from four classes of bookings when they are confronted with prisoner behavior that warrants a disciplinary report. In general, Class 1-Highest bookings are those offenses which are viewed as extremely serious; they may or have resulted in the injury of staff or other prisoners and/or may or have resulted in seriously compromising security at the institution. $\underline{5}$ Class 1 -Highest is further divided into two categories, Predatory and Non-Predatory. Class 2-High bookings have the same general categories, but these offenses are not considered as serious or as threatening to the security of the facility. Classes 3-Moderate and 4-Low Moderate are progressively less serious, with the latter only including about 10 offenses such as not making one's bunk properly, fishing, littering, and poor job performance. $\underline{6}$

Diagram 1. Steps in RIDOC booking process

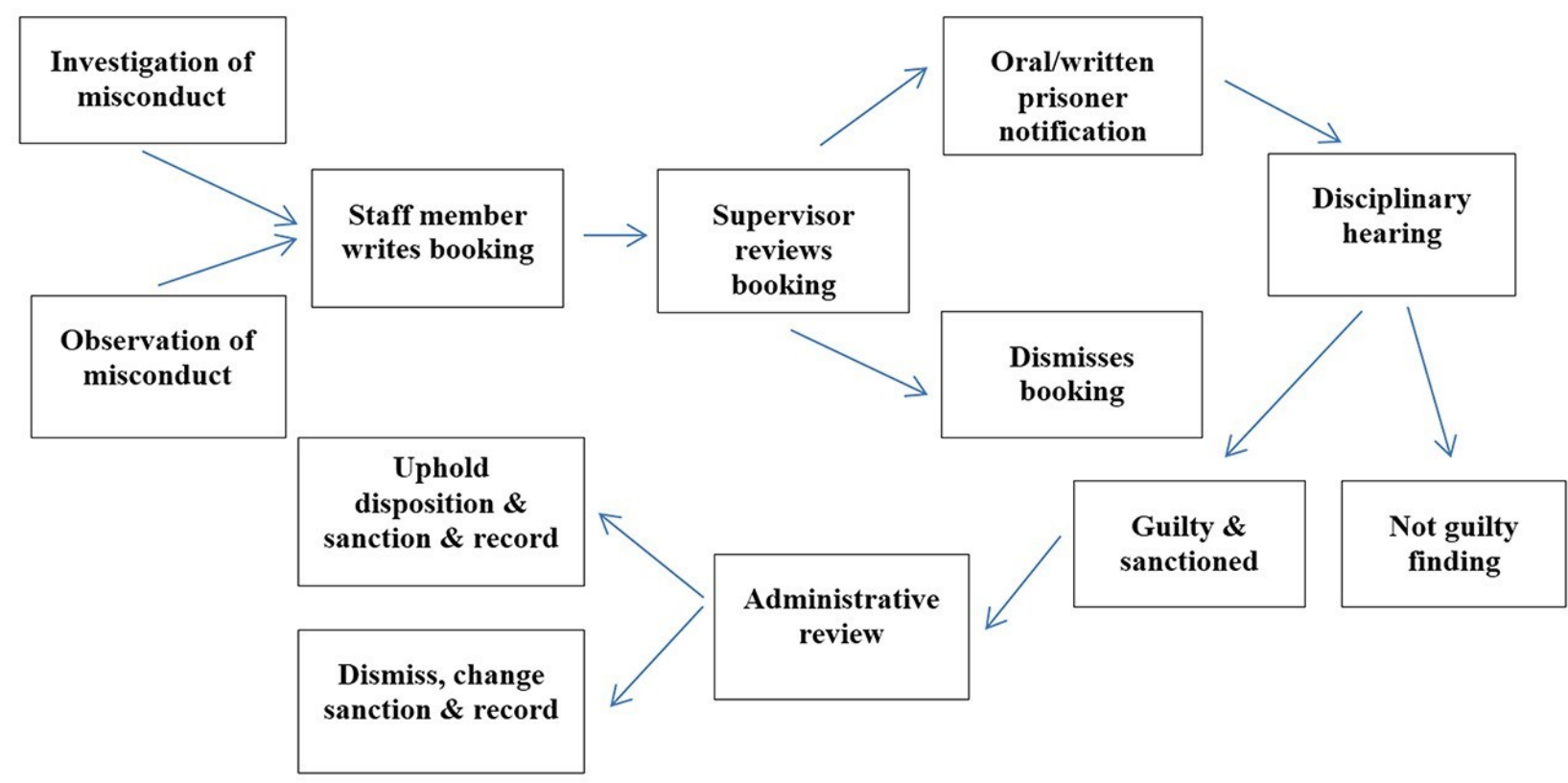

There are six mandatory steps associated with any booking: initial booking report; a timely supervisor review for accuracy and appropriateness; prisoner notification orally and in writing within 24 hours of the event; the disciplinary hearing; administrative review; and the recording of the booking and the 
results of the hearing in INFACTS (INmate FACility Tracking System) (RIDOC, 2009). Concomitantly, by policy, mental health staff at each facility checks INFACTS on a daily basis for all bookings to determine whether any of them might have been a result of a prisoner's mental health status (RIDOC, 2007). If so, the Warden may be notified and could then decide to dismiss the booking or let it proceed to a hearing.

The prisoner is offered a representative at the hearing (usually a correctional counselor) who meets with the prisoner prior to the hearing and helps him prepare a defense and make a presentation at the formal disciplinary hearing. The disciplinary hearing is presided over by the Hearing Officer, a lieutenant at each facility who has been designated for such duty. Prisoners are present throughout the hearing unless they refuse to appear, their behavior gives cause for exclusion or removal, and except during the time that confidential information is being presented, or the Hearing Officer recesses for deliberation. At the hearing, the charge is read, the prisoner is asked to enter a pleaguilty, guilty with an explanation, or not guilty (RIDOC, 2009). After presentation of witnesses and evidence, questioning of the prisoner regarding the circumstances and motivation of the offense, and rebuttal by the prisoner, the Hearing Officer has several options. These include dismissal of the charge; revision of the booking charge with a guilty finding; issuance of a guilty finding and a reprimand; or, the most prevalent option, issuance of a guilty finding and the sanctioning of the prisoner.

Sanctions for bookings can include a referral to the Classification Board for a review of the prisoner's classification status; temporary loss of privileges for up to 15 days; disciplinary confinement up to one year; restitution; or any combination of these sanctions (RIDOC, 2009). The number of days of disciplinary confinement is dependent on the class level of the booking. - In addition, by policy, prisoners lose the same number of days of good-time as the number of days in confinement or the number of days of loss of privileges. For example, if a prisoner assaulted a staff person and was sanctioned to eight months in segregation, he would also lose eight months of good-time and could not earn any new good-time during that period.

After deliberation, the Hearing Officer immediately informs the prisoner of the decision of guilty/dismissal and the sanction and asks the prisoner if he would like to appeal the decision (RIDOC, 2009). Sanctions exceeding 30 days trigger an automatic review by the Warden; those exceeding 90 days and upheld by the Warden trigger an automatic review by the Assistant Director of Institutional Operations. Both can uphold the decision; order further investigation; alter the infraction or the sanction; or dismiss the booking outright. Either way, prisoners are notified in writing of the final outcome of appeals and all information is made available to relevant staff and is entered into the INFACTS database. 


\section{Research methods}

\section{Data collection}

This qualitative research was conducted between 2009 and 2010 in the John J. Moran Medium Security Facility (hereafter referred to as the Moran facility), the Donald Price Medium Security Facility (hereafter referred to as the Price facility), the Maximum Security facility, and the High Security Center (HSC), a supermax-like facility built in 1981 that is separate but on the grounds of the RIDOC. The data collection had two components, direct observation of classification and disciplinary hearings; and in-depth inter-views with staff and with prisoners who had been involved in serious misconduct and violence.

There is a rich tradition of conducting qualitative prison research beginning with the early ethnographies of prison subculture (Clemmer, 1940; Sykes, 1958). Qualitative research in prison continues (Carroll, 1974; Earley, 1992; Irwin, 2005; Johnson \& Toch, 1988; Liebling, 2000; Owen, 1998; Schlosser, 2008; zamble, 1992), though these investigations have been less prevalent than quantitative research (Miller, 2005; Tewksbury, 2009). Qualitative research has been used to examine prison processes, discretionary decision-making practices, and to understand prisoners' behavior (Miller, 2005; Worley, 1992). In-depth interviews are "structured conversations" with individuals using openended questions to elicit subjects' meanings, understandings, feelings, and reasons about various issues (Schlosser, 2008; Tewksbury, 2009). In-depth interviews of prisoners, correction officers, and administrators have been used to elicit rich accounts of prison life and to gain a deeper understanding of the perceptions, behaviors, and motivations of these subjects (Earley, 1992; Irwin, 2005; Liebling, 2000; Schlosser, 2008; zamble, 1992). Direct observation involves a systematic investigation of people's interactions and actions within certain settings and is used by prison researchers mainly to understand prisoner/staff interactions (Liebling, 2000; Owen, 1998; Tewksbury, 2009).

Direct observation in this research involved observation of classification and disciplinary hearings at each of the four facilities. The classification hearings of 57 prisoners were observed including 13 at Price, 15 at Moran, 21 at Maximum, and 8 at the HSC. The disciplinary hearings for 44 prisoners were observed including 15 at Price, 9 at Moran, 12 at Maximum, and 7 at the HSC. Observing classification and disciplinary hearings was essential to understanding the processes by which prisoners are sanctioned and possibly classified to higher security at either maximum security or the HSC.

Staff interviews were conducted in private offices or in rooms where classification and disciplinary hearings take place and took from 30 minutes to about 90 minutes depending on the length of the staff responses. Staff members were specifically asked, "What do you think of the current disciplinary process? Of the current sanctioning process? Are there other sanctions/solutions that you would like to see implemented?" 
Individual prisoner interviews were conducted in a classroom in Moran, in the cafeteria in Maximum, and in either the dining area or an interview room in the housing units at the HSC and took from one

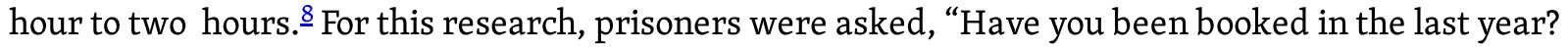
In general, do you think the bookings issued are fair? Did you go through a disciplinary process? What do you think of the disciplinary process? Is it fair? Are the sanctions fair?" and what changes, if any, they would like to see implemented.

\section{Participants}

Initial casual conversations with staff at each of the facilities helped to build relationships that resulted in greater staff participation in the interviews and gave the researcher ideas to pursue in both staff and prisoner interviews. In-depth interviews were conducted with 25 staff members from the two medium facilities (Moran and Price), from Maximum Security, and from the HSC. All staff members were chosen because they had dealings with prisoners with high levels of serious misconduct and violence. The interviewees included all of the deputy wardens (5) from these facilities, both wardens, and all of the lieutenants (6) who conducted disciplinary boards at these four facilities, as well as an administrator of classification. A correctional counselor chosen by convenience was interviewed at each of the three different facilities. Finally, 5 correction officers and 2 lieutenants at the HSC were also chosen by convenience with interviews continuing until the researcher had achieved at least 25 total interviews and the time allotted to be at HSC collecting data was at an end. The captain of the facility, also interviewed, made it known to correction officers and lieutenants that the researcher was looking for volunteers to participate in a confidential in-depth interview and had asked many of the uniformed staff to participate during the course of other data collection at that facility.

Responses among staff were categorized by respondent rank only when patterns emerged that had to do with rank (e.g., a number of the correctional officers had one opinion whereas the supervisors thought otherwise). To maintain anonymity, the wardens and deputy wardens are referred to as administrators; the captains and lieutenants are referred to as supervisors; the member of the central office classification staff is referred to as a correctional counselor; and the four females are referred to as "he." Responses among prisoners are only categorized by place of interview/status when patterns emerged that had to do with where one was housed at the time of the interview.

Of the 162 prisoners with a serious booking during 2008 who had completed the survey for the larger study on coping, 100 prisoners (62\%) agreed to an in-depth interview. 9 The initial plan was to select a purposive sample representative of at least race/ethnicity, age, and facility. However, the choice of 25 prisoners from a pool of 100 prisoners provided the opportunity to ensure even greater representativeness of those involved in serious misbehavior. After initial perusal of survey results, observation of disciplinary hearings, and staff interviews, patterns emerged about the types of 
prisoners involved in serious misconduct and violence. Thus, a decision was made to also choose prisoners from these types: young prisoners; those who were in a street gang; those who had previously been adjudicated delinquent and committed to a juvenile facility; those with prior mental health problems; and drug abusers. Many of these categories overlapped, but attempts were made to interview 4 to 5 prisoners from each of these categories while still being representative of age, race/ethnicity, and facility.

This exploratory research used a grounded theory approach to devising themes and propositions about the prison disciplinary process (Hesse-Biber \& Leavy, 2006). The bulk of the data for this study came from staff and prisoner responses to sets of questions about the disciplinary process. The responses to each individual question were extracted from individual interviews and grouped together; responses were then tallied. As themes and propositions emerged, the transcript of the remainder of the indepth interviews was searched to find other mentions of these propositions, such as prisoners being buried in segregation, staff consistency in issuing bookings, and staff disrespect of prisoners. These were added after each question's summary. As the propositions emerged, they were resonant of findings in the procedural justice and defiance literature and were reviewed again and re-categorized in light of that literature.

\section{Findings}

Almost all of the interviewed staff and prisoners provided feedback on the disciplinary policy, the issuance of bookings, and the disciplinary process, including investigation, the board, appeals, and sanctions (Table 1). There was a marked difference between staff responses (more often positive) and those of prisoners (more often negative).

Table 1. Prisoner and staff perceptions of the disciplinary process

\begin{tabular}{|l|l|l|l|l|}
\hline $\begin{array}{l}\text { Prisoner Questions } \\
\text { (n=25) }\end{array}$ & Yes & Depends & No & Not answered \\
\hline $\begin{array}{l}\text { Do you think the } \\
\text { bookings issued are } \\
\text { fair? }\end{array}$ & 2 & 8 & 12 & 3 \\
\hline $\begin{array}{l}\text { Is the disciplinary } \\
\text { process fair? }\end{array}$ & 3 & 3 & 16 & 3 \\
\hline $\begin{array}{l}\text { Are the sanctions } \\
\text { fair? }\end{array}$ & 2 & 6 & & \\
\hline
\end{tabular}




\begin{tabular}{|l|l|l|l|l|}
\hline Staff $(\mathrm{n}=25)$ & Favorable & Mixed & Unfavorable & Not answered \\
\hline $\begin{array}{l}\text { HSC correction } \\
\text { officer }\end{array}$ & 1 & 3 & 1 & 0 \\
\hline Classification staff & 1 & 0 & 3 & 0 \\
\hline Supervisor & 3 & 3 & 3 & 0 \\
\hline Manager & 4 & 3 & 0 & 0 \\
\hline
\end{tabular}

Staff members' overall comments about the disciplinary process in general were categorized as favorable, unfavorable, or mixed. A little more than one-third of the staff ( 9 of 25) comments were completely favorable, one citing the change in policy as a "remarkable improvement over the old one" and another saying that "when [the policy] was revamped, it was for the better." Throughout various portions of the interview, staff commented that the policy had a deterrent effect on prisoner misconduct, and that it provided more flexibility to correctional officers in choosing a booking level. However, a little more than one-third of the staff ( 9 of 25) gave the disciplinary process mixed reviews. These staff most often said that the policy itself was very good, but that the implementation of the policy was problematic. Seven staff did not have favorable opinions about the disciplinary process or its implementation.

\section{Bookings}

Staff gave both positive and negative feedback on the booking options (the categories and levels of individual charges that officers choose from when writing a booking). The previous policy only offered a few dozen booking options, whereas there are over 160 different charges in the new policy. The HSC COs liked the new booking options. However, three of the five said that many of the prisoners coming into the HSC did not care about increasing times in segregation and that overall, bookings were not a deterrent. Managers commented that the booking options provided officers with a "menu of infractions to choose from" and that it contained a "lot of very specific infractions" to cover many more situations than the prior policy covered. However, one of the supervisors felt that the codes were either "too generic or too specific, [that it was sometimes] hard to fit [bookings] into them," and that many officers were not sure what to do with the discretion. He said, and at least two officers acknowledged, that it was a common practice to book the misbehavior into a higher class than warranted because they thought it would be lowered anyway. Another supervisor thought that the class levels of some of the codes were too high and that others were toolow, that some staff would try to fit the booking into a category that matched the sanction they thought appropriate. One supervisor suggested that there needed to be more education about the codes for both prisoners and staff. He felt 
that prisoners should be apprised of the behaviors that they could be booked for and that staff should be given more training on how to choose booking categories.

More than two-thirds of the prisoners (18 of 25) interviewed had been booked in the year prior to the interview and almost all had had a serious booking either during that year or the year prior. When asked if the bookings were fair, 2 of the 23 prisoners responded affirmatively. Of the remainder, almost half said "no" and the others said that it depended, that sometimes bookings were fair, and sometimes they were not. In their responses, many prisoners acknowledged their responsibility for their bookings; one responded that he thought the bookings he had received were fair because he "caused them."

There were three reasons that prisoners gave for why they thought bookings were unfair, "pettiness" of bookings; bookings for behavior they did not commit; and inconsistent bookings. By far, the most prevalent complaints were that officers gave out bookings for minor misconduct. One prisoner complained, "There are certain bookings that are petty ... the stuff they put you in segregation for ... if you stick the mirror out the doorway, they book you ... there are too many items. I could see if I had a weapon or was threatening somebody." Prisoners called many of the charges "frivolous" and gave as examples being booked for eating slow, praying, and not tucking in your shirt. A prisoner from HSC explained that before the policy change, there were fewer types of infractions but now prisoners could get booked for petty things. Another prisoner from Maximum noted the severe consequences of petty bookings, "When you're in seg, you lose a bit of yourself ... don't hold a guy in seg for 30 days because he has ketchup." Another said that some prisoners had been booked for having braided hair; "that's not in the rule book ... cops have their own rules and pick on whoever they want to pick on." A couple of prisoners also noted that rookie officers were the most likely to give out "petty" bookings "as notches on their belt."

While prisoners mostly complained about "petty" bookings, the dozens of examples they gave of unfair bookings were most often those they denied doing. Prisoners claimed that many bookings had been fabricated by officers who disliked them. For example, one gave a typical scenario, "Say you're sleeping and it's count time. If the officer doesn't like you, he'll book you for not standing for count. You can get 30 days and a downgrade. He'll write that he banged on your door, when really he didn't even try to wake you up." Many mentioned, as one said, that "it is always your word against theirs." Another prisoner recounted that once when an officer grabbed him, he pushed him off but was written up as if he had assaulted the officer, "I never had proof that he hit me because the tapes [in the camera] were not on ... I just did my seg time."

Finally, prisoners complained about inconsistencies in booking; some officers will let certain behaviors go while other officers would book prisoners at first sight of the same behavior. One prisoner recounted being booked for having extra food but explained that the officers on the second shift 
usually allowed it. One prisoner said that he had been booked 27 times in the past year, 24 times by the same officer. He said that other officers had come by to tell him that he should not have been booked. In addition, prisoners reported that some prisoners who had been incarcerated a long time were often given more slack.

\section{The disciplinary hearing}

While almost four-fifths of staff (18 of 25) either completely or partially approved of the overall disciplinary process, almost an equal number felt that the process needed some improvements (9) or a lot of improvement (7). Overall, out of the 22 prisoners who responded to the question about the fairness of the disciplinary process, 16 thought it unfair, 3 said it was fair, and 3 others said that it was sometimes fair. Some were dramatic in their criticisms calling disciplinary boards "kangaroo courts" or run like "Hitler's court." Specifically, staff brought up three main areas where they believed the process could be improved: investigation; use of confidential informants; and disciplinary board makeup. $\underline{10}$ Prisoners identified those same problems but were also critical of other aspects such as the lack of an advocate and the preponderance of guilty findings.

According to the policy, a warden's designee, usually a lieutenant, is supposed to review a disciplinary report, investigate it if it is appropriate, and determine if it is properly written and whether the charge matches the behavior discussed. Three supervisors running disciplinary boards complained about the lack of investigation, about the lack of available evidence, and that bookings triggered by the Special Investigative Unit (SIU) staff lacked specific details. One supervisor said if proper investigations were not carried out, "it opens up the door for mistreatment by staff." He explained that investigators should speak to both the reporting officer and the prisoner and look into any questions that the prisoner might raise. Some staff believed that bookings in which the prisoner was truly not guilty should be thrown out by the investigating officer before getting to a hearing. One example given by a correctional counselor involved a prisoner who was booked for having excess property because he had multiple pillows on his bed. He was put in segregation, even after explaining that it was his job to hand out pillows to prisoners. The counselor said the matter should not have reached the disciplinary board since the prisoner's story could easily have been corroborated beforehand.

Those prisoners who felt that they had been unfairly booked often specified the lack of investigation as a problem. As one protested, "They need to investigate more instead of all believing what the cops said. Because we're in jail, [they think] we're all bad, that we're all liars." Similarly, a handful of prisoners complained that they were not allowed witnesses even though they were supposed to have them by policy. They said that the disciplinary officer often told them that they should not bother, that the witnesses were not needed. 
Closely associated with the lack of investigation was the use of confidential informants. One staff person acknowledged that when a booking was triggered by a confidential informant (CI) that the disciplinary board was a formality because only the warden could question a CI. A supervisor complained about the overuse of CIs, and how they were usually the same ones. Though CIs were supposed to be trustworthy and give good information, he wondered if they were and what their motivations were for stepping forward. He said that bookings by SIU with CIs were usually two or three lines, and there was nothing to do at the hearing but find the prisoner guilty. He gave as an example one prisoner charged as a mule for bringing in drugs. The prisoner had had no prior criminal or institutional history of drug use or sales and had adamantly denied the charge, but the CI's complaint was deemed sufficient, and the supervisor had to find him guilty. One prisoner explained that he had tried to tell the board that if another prisoner did not like him, "all they need to do is go to a CO and say I'm doing something."

Four staff, mostly correctional counselors, did not like the change in the policy that reduced the number of people on a disciplinary board (d-board) from three to one. As one counselor put it, "I don't like how the d-boards are run. I like the old way, an officer, a counselor, and the lieutenant, and each had an equal vote. Now it's left to one person to be the judge and jury. If you have a lieutenant who is not particularly fair or who does not have favorable views of the prisoners, it's not a fair process." Another explained that correctional counselors often know a prisoner better than the lieutenant running the disciplinary board and that if they have a say, they can point out situations that do not make sense and can explain circumstances. He explained that he once sat on a d-board where a prisoner had been booked for not standing for count. He knew this prisoner always stood for count, and that he was about to go before the Parole Board. Despite being adamant that he did stand for count, he was found guilty. The counselor pursued it, finally showing a picture of the prisoner to the rookie officer who had written the report, and who then realized he had booked the wrong prisoner. The counselor reported that had he been on the d-board, he would have insisted on more investigation before finding the prisoner guilty.

While many staff credited the change in personnel on the d-board with making the d-boards more consistent, a handful said that there was little consistency among the lieutenants doing the disciplinary boards, and that some let their opinions of prisoners affect their decisions. At least 3 of the prisoners explained that whether the disciplinary process was fair or not depended on which lieutenant was conducting it and what his mood was that day.

Many prisoners believed that going to the disciplinary board was a waste of time, since one was nearly always found guilty. As one prisoner put it, "if you get booked, $99 \%$ of the time that booking is sticking. It's rare to get thrown out. That's in every building, [because it is] your word against the cops." Prisoners often spoke about how officers sided with each other; as one explained, "If you're a 
lieutenant and an officer books somebody, you're going to take his side. You're his brother. It's different if it was a deputy doing it." They complained that in addition to the lack of evidence, hearing officers often did not take extenuating circumstances into account. They also complained that nobody advocated for them. While some acknowledged that they could request a counselor's presence, they explained that often the disciplinary officer discouraged it, by saying, "do you really want us to get ?" and often the prisoner decided that it was probably not worth it. One explained the importance of a counselor's presence to "represent you, give you advice on how to deal with the problem, how to address it at the board, what the scenario might be. Somebody to give us advice. You want to do the right thing; you don't want to dig yourself deeper in a hole."

\section{Severity of sanctions}

Many staff hailed the changes in the policy that increased the potential time in segregation from a maximum of 30 days to a new maximum of one year in order to address the most serious forms of misconduct. One correctional counselor said the change in policy had had a big deterrent effect because for prisoners there was a "big difference between 30 days and 365 days in segregation." One administrator felt the change had been necessary because, under the old policy, no matter how horrendous an offense had been, they could only sanction prisoners to 30 days of segregation.

Four of the staff interviewed felt that sometimes the sanctions given were too harsh. One supervisor who conducted d-boards felt that he and his colleagues should be given more latitude regarding lengths of sanctions. He felt that more consideration should be given regarding a prisoner's past behavior, especially in those instances where it was the prisoner's first booking. He said that in those circumstances, sometimes the booking did not warrant segregation, and that the sanction ranges were not progressive enough. Two administrators and a supervisor said that sometimes staff tended to sanction on the harsh side, and that they needed to "keep an eye on it "cause people can get heavyhanded." One supervisor wanted the serious consequences of the loss of good time to be brought to the attention of both staff and prisoners so that COs would charge appropriately, d-board officers would sanction fairly, and prisoners would avoid misconduct if they realized how much longer they would have to serve as a result of the good-time lost.

Only 2 of the prisoners interviewed thought the level of sanctions given was fair. One said, "[It's] all right, if you're wrong, you're wrong," and the other said that "people don't usually say they got more than they deserved." Six prisoners said fairness depended again on who was conducting the d-board, that "some are fair and some are not." However, over half of the prisoners (13 of 21) interviewed said that sanctions were unfair; however, not one complained of the new guidelines that allowed sanctions to segregation of up a year. 
Most of the complaints were that disciplinary officers gave the maximum penalty; that segregation lengths were too long for many smaller offenses; and that in Maximum and the HSC, one could get "buried in seg time." A number of prisoners protested that some of the lieutenants conducting the boards always gave the maximum and always gave out segregation time. They variously described the amount of time as being "too much," "too punitive," and "too drastic." One prisoner complained that "even if you tell you did it and you show remorse, he still gives you the max, no matter what." Another griped that he had gotten 15 days confinement to his cell for having an extra apple. One prisoner could not produce a urine sample on demand, was booked, and received 26 days of segregation and loss of good-time, six months loss of visits, 90 days on B status, and loss of his job. He said he really could not urinate, had not been given a second chance before being booked, and thought the punishment too harsh. Some prisoners thought that alternatives to segregation could be used, like taking away one's radio or $\mathrm{TV}$.

\section{Segregation}

Both staff and prisoners talked about that small percentage of prisoners who were "buried in seg." The half-dozen HSC staff who questioned the efficacy of "burying prisoners in segregation," averred that prisoners who accumulated a lot of time in segregation either wanted to live in segregation or had so much segregation time built up that they had nothing to lose. Of the first scenario, one correction officer articulated that in order "for discipline to work, you have to take something away that they want. [But] to some of them, [being in the HSC is] a better life. They don't have to cope with the prison society." He concluded that sanctions were only good if they "matter." Regarding the efficacy of segregation, one CO said, "You have the inmates with so much time racked up. The general opinion of people is that more of the same is insufficient." Another supervisor said, "Some are doing so much time, in their head, it's doesn't matter. Some flatten [have their sentence expire] before their segregation time is done."

A half-dozen prisoners interviewed reported that they were or had been "buried in seg" but only one of those said it had been his choice; he admitted to bizarre behavior in Maximum in order to be transferred to the HSC. 11 The others discussed how difficult it was to get out of segregation. One said, "If you are working hard to be on the right path and get booked for something small, like 20 days seg for borrowing someone's magazine, it makes me feel like, 'what am I being good for? I may as well be bad." Some prisoners agreed that after a while in segregation, it became easier, that one did grow used to it. For example one explained, "Here, you keep getting seg time, but once you get used to not having visits and you don't have any money to buy stuff, it doesn't matter anymore if you get more seg time. [People] get to the point where they have nothing to lose, nothing to do." However, not all prisoners found it easy to spend lengths of time in segregation. For example, one said, "It messes a lot of people's head up. I'm going on two years now, I think I'm going to be worse off than I was before ... going back into population with so many people." He continued that sometimes he would start having 
"bad thinking ... you start kicking your door and flooding your cell. You don't care anymore cause you're buried doing time in seg."

One administrator explained that prisoners in long-term segregation in both the HSC and in Maximum were reviewed by the warden every 90 days, who by policy had the ability to suspend segregation days. The warden uses the review to empower officers, telling the prisoner that if officers report that he is doing well, some of the segregation time will be suspended. One counselor said that once prisoners realize they cannot beat the system, they often take advantage of an offer like "You show me you're good for the next 60 days, and I'll cut you a break."

\section{Discussion}

\section{Legitimation, procedural justice, and defiance}

The greatest number and variety of complaints of unfairness focused on distributive fairness, especially as it pertained to the fairness of bookings and disciplinary procedures. Prisoners labeled bookings as "unfair" if they were petty, if the inmate had been falsely accused or had reasonable explanations for his behavior, and if staff were inconsistent in their bookings. Indeed, in his explanation about the differences between "all right cops" and those that prisoners labeled "assholes," Irwin (2005) clarified that the former were consistent and fair in both the uniform application of rules and in their lack of pettiness. "Asshole" cops were more likely to enforce rules in a "chicken shit" manner-petty, inconsistent, unfair, and non-empathetic. In addition to the perceived unfairness of bookings, two-thirds of the prisoners in this study assessed both the disciplinary hearings and the sanctions received to be unfair. Prisoners believed the sanctions were unfair because they almost always received the maximum sanction, especially in some facilities. Others stated that even lesser offenses almost always resulted in segregation or cell time that was too long; and some prisoners in the HSC and Maximum ended up being "buried in seg" with little hope of leaving.

One can readily apply Paternoster and colleague's six components of procedural justice to the RIDOC disciplinary process (1997, pp.167-168). Representation is important to prisoners because they expect to have the opportunity to tell their story about what happened in the booking - to explain extenuating circumstances and the decisions they made. RIDOC prisoners discussed instances where they had mitigating circumstances regarding an incident, but that staff did not sufficiently investigate the incident or consider extenuating circumstances before making a determination. Prisoners complained about the lack of consistency practiced by correctional officers. Prisoners thought correction officers were unfair when they favored certain prisoners or when they were not consistent in their bookings, allowing some prisoners to violate the rules, but writing bookings for others for the same behavior. In addition, they complained about the lack of consistency from one officer to the next, which resulted in never quite knowing which minor rules would be enforced. Regarding impartiality, prisoners complained that correction officers had a severe bias against prisoners and viewed them as almost less 
than human. They stated that certain lieutenants conducting the d-boards let their biases affect outcomes and sanctions. Some staff and prisoners believed that having only one lieutenant conduct the d-board was unfair and exacerbated problems of bias and inconsistency rather than reducing those problems as intended. Prisoners and staff were concerned about accuracy. Staff and prisoners questioned whether there was sufficient investigation of bookings to ensure they were accurate, properly classified, and properly charged. Some staff were wary of the regular use of confidential informants, especially in bookings where there was no corroborating evidence, and the prisoner charged was adamant that he had not engaged in that behavior. On the issue of correctability and the ability to appeal to a higher authority, the RIDOC does have a policy whereby prisoners can appeal findings of the d-board. Only two prisoners brought up a complaint about the appeals process, saying that appeals were a waste of time because guilty findings and, less often, sanctions were always upheld in appeals. The final component, ethicality, has to do with whether prisoners felt they were treated with respect and dignity, and whether correctional officers and authorities were moral, legitimate, and deserving of compliance. Though no specific questions about the disciplinary process touched specifically upon ethicality, one could conclude from prisoners' overall comments in the indepth interviews that they felt disrespected by officers and that they interpreted officers' words and actions as immoral and illegitimate.

If defiance theory is applied (Sherman, 1993) to this disciplinary process, one would conclude that prisoners who felt that the overall disciplinary process was procedurally unfair and who felt disrespected would not focus on what they did wrong, but on the unfairness of the situation. They would not learn the lesson from the process, nor would they feel the appropriate guilt. Instead of being shamed into future adherence to rules, their defiance would ensure that rule-breaking would continue. Thus, their defiance might result in a seemingly never-ending cycle of escalating misbehavior. Bottoms (1999) asserted that the incorporation of legitimation into prison practice was not just about being nice to prisoners and giving them what they wanted. Procedural justice was more about prisoners' perceptions of fairness and feeling respected. Bottoms concluded "if one is unable to provide, on reasonable request, a morally justifiable account of decisions made, then this may ultimately be instrumental in producing just the kinds of disorders that wardens and staff want to avoid" (1999, p. 257).

\section{Future research and conclusion}

This research highlighted staff and prisoner perceptions of the disciplinary process in one single state. While further research is recommended to delve into the components of fairness or a replication of the study of Rhode Island's disciplinary process five years from the policy's revamping, the findings of this study generate research questions that could be examined in any prison system. For example, more research needs to be conducted on the connection between legitimation, procedural justice, and prison misconduct. 
1. How do prisoners' perceptions of fairness vary?

2. How much are their perceptions of fairness associated with involvement in serious misconduct and violence?

3. Are prisoners' ideas about procedural justice, especially as they pertain to the disciplinary process, similar?

4. Which dimensions of procedural justice are most likely to result in defiant vs. compliant future behavior?

Research could also focus on the characteristics of prisoners to determine if certain types of prisoners have an inclination to react defiantly to perceived unfairness compared to others.

A great deal of research attention has been paid to those individual, situational, and prison-level factors that affect the amount of misbehavior in our prisons. However, little attention has been bestowed on the prison disciplinary process itself. This small, exploratory research was a step toward learning about the various aspects of the disciplinary process, but also staff and prisoners' perceptions of fairness of the process. Prisoners' overall assessment of this process as negative is general knowledge to anyone who has conducted research or worked in a prison. However, while staff members' overall assessments of the disciplinary process were positive, more than half of the staff highlighted problems associated with fairness that substantiated prisoners' complaints of legitimation.

This research highlighted those features of the disciplinary process that prisoners and some staff assessed as problematic and unfair. These included the nature, consistency, and investigation of bookings; the use of confidential informants; the staffing of d-boards; the use of segregation time for non-serious offenses; and the long-term segregation of some offenders. Every prison disciplinary system has policies and procedures that address these issues. Prison administrators should recognize the importance of prisoners' perceptions of both staff and distributive fairness. If prisoners gauge staff and disciplinary processes to be unfair, it reduces the legitimacy of the disciplinary process regime and may be counterproductive to prison administrators' goals of reducing serious prison misbehavior and violence.

\section{References}

Adams, K. \& Ferrandino, J. (2008). Managing mentally ill inmates in prisons. Criminal Justice and Behavior, 35, 913-927.

Arrigo, B. A., Bersot, H. Y., \& Sellers, B. G. (2011). The ethics of total confinement: A critique of madness, citizenship, and social justice. Oxford, UK: Oxford University Press.

Babcock, W. (1980). Due process in prison disciplinary proceedings. Boston College Law Review, 22, 10091096. 
Bottoms, A. (1999). Interpersonal violence and social order in prisons. In Tonry \& J. Petersilia (Eds.), Crime and justice: A review of research (volume 26, pp. 205-281). Chicago: University of Chicago Press.

Carroll, L. (1974). Hacks, blacks, and cons. Lexington, MA: Lexington Books.

Clemmer, D. (1940). The prison community. New York, NY: Holt, Rinehart and Winston.

Earley, P. (1992). The hot house: Life inside Leavenworth. New York, NY: Bantam Books.

Fellner, J. (2006). Corrections quandary: Mental illness and prison rules, Harvard Civil Rights-Civil Liberties Law Review, 41, 391-412.

Flanagan, T. J. (1982). Discretion in the prison justice system: A study of sentencing in institutional disciplinary proceedings. Journal of Research in Crime and Delinquency, 19, 216-237.

Fleming, T. J. (1981). Noble holdings as empty promises: Minimum due process at prison disciplinary hearings. New England Journal on Prison Law, 7, 145-192.

Hesse-Biber, S. N., \& Leavy, P. (2006). The practice of qualitative research. Thousand Oaks, CA: Sage Publications.

Hewitt, J. D., Poole, E. D., \& Regoli, R. M. (1984). Self-reported and observed rule-breaking in prison: A look at disciplinary response. Justice Quarterly, 4, 436-447.

Howard, C., Winfree, L. T., Mays, G. L., Stohr, M. K., \& Clason, D. L. (1994). Processing inmate disciplinary infractions in a federal correctional institution: Legal and extralegal correlates of prisonbased legal decisions. The Prison Journal, 74, 5-31.

Irwin, J. (2005). The warehouse prison: Disposal of the new dangerous class. Los Angeles, CA: Roxbury Publishing.

Johnson, R. \& Toch, H. (1988). The pains of imprisonment. Prospect Heights, IL: Waveland Press.

Jones Jr., C. H., \& Rhine, E. (1985). Due process and prison disciplinary practices: From Wolff to Hewitt. New England Journal on Criminal \& Civil Confinement, 11, 44-122.

Liebling, A. (2000). Prison officers, policing and the use of discretion. Theoretical Criminology, 4, 333357.

Lovell, D., \& Jemelka, R. (1996). When inmates misbehave: The costs of discipline. The Prison Journal, $76,165-179$.

McCorkle, R. (1992). Personal precautions to violence in prison. Criminal Justice and Behavior, 19, 160-173. 
McShane, M. D. (2008). Prisons in America. New York, NY: LFB Scholarly Publishing.

Miller, J. (2005). The status of qualitative research in criminology. Paper presented at the National Science Foundation's Workshop on Interdisciplinary Standards for Systematic Qualitative Research on May 19-20, 2005 in Washington, DC.

Owen, B. (1998). In the mix: Struggle and survival in a women's prison. New York, NY: State University of New York Press.

Paternoster, R., Brame, R., Bachman, R., \& Sherman, L. S. (1997). Do fair procedures matter? The effect of procedural justice on spouse assault. Law \& Society Review, 31, 163-204.

Poole, E., \& Regoli, R. (1980). Race, institutional rule breaking and institutional response: A study of discretionary decision making in prison. Law and Society Review, 14, 931-946.

Reisig, M. D., \& Mesko, G. (2009). Procedural justice, legitimacy, and prisoner misconduct. Psychology, Crime \& Law, 15, 41-59.

Rhode Island Department of Corrections (RIDOC). (2007). Management of offenders whose emotional/psychiatric status presents a danger to self or others: RIDOC policy and procedure 18.51-1 DOC, effective date 2/12/07. Cranston, RI: RIDOC.

Rhode Island Department of Corrections (RIDOC). (2009). Code of inmate discipline: RIDOC policy and procedure 11.01-5 DOC, effective date 3/9/09. Cranston, RI: RIDOC.

Rocheleau, A. M., Forcier, M., \& Jackson, J. (1998). Evaluation of the Massachusetts Department of Correction Department Disciplinary Unit. Unpublished report prepared for the Massachusetts Department of Correction.

Rocheleau, A. M. (2011). Prisoners' coping skills and involvement in serious prison misconduct and violence (Dissertation). Northeastern University, Boston, MA.

Schlosser, J. A. (2008). Issues in interviewing inmates: Navigating the methodological landmines of prison research. Qualitative Inquiry, 14, 1500-1525.

Sherman, L. (1993). Defiance, deterrence, and irrelevance: A theory of the criminal sanction. Journal of Research in Crime and Delinquency, 30, 445-473.

Steinke, P. (2001). The effect of inmates' accounts on disciplinary penalties. The Journal of Social Psychology, 132, 475-485.

Sykes, G. M. (1958). The society of captives. Princeton, NJ: Princeton University Press. 
Tewksbury, R. (2009). Qualitative versus quantitative methods: Understanding why qualitative methods are superior for criminology and criminal justice. Journal of Theoretical and Philosophical Criminology, 1, 38-58.

Tyler, R. T. (1990). Why people obey the law. New Haven, CT: Yale University Press.

Worley, R. M. (1992). To snitch or not to snitch, that is the question: Exploring the role of inmate informants in detecting inappropriate relationships between the keeper and the kept. Texas International Review of Law, Computers \& Technology, 25, 79-82.

Zamble, E. (1992). Behavior and adaptation in long-term prisoners. Criminal Justice and Behavior, 19, 409-425.

\section{Contributor}

Ann Marie Rocheleau is an Assistant Professor in Sociology and Criminology at Stonehill College in Easton, Massachusetts. Her current research examines prison operations and culture and their effects on inmate violence. Previously, she served as Program Coordinator for the nationwide Council of Juvenile Correctional Administrators, working to raise the conditions of confinement in juvenile correctional facilities. She began her career conducting research at the Massachusetts Department of Correction and moved into management in the area of programming.

\section{Footnotes}

1. 418 U.S. 539 (1974). $\doteq$

2. Madrid v. Gomez, 90-3094 N.D. California (1995); Jones 'el v. Berge, 00-C421-C W.D. Wisconsin (2001). $\Xi$

3. Ahmad, S. (1996). Fairness in prison. Ph.D. dissertation, University of Cambridge. $\uplus$

4. The larger study examined whether ways of coping and trait emotions were related to serious misconduct and violence in prison. This study involved a self-report survey of 312 prisoners in the Rhode Island Department of Correction, direct observation in classification and disciplinary hearings, and in-depth interviews with 25 prisoners and 26 staff. Data for this exploratory study on the disciplinary process were derived from direct observations and several questions in the in-depth interviews. (Rocheleau, 2011)..

5. Class 1-Highest Predatory bookings include escape; sexual assault; arson; assault on staff, on other prisoners, or any other persons; extortion; hostage-taking; killing; mayhem; robbery; and rioting. Class 1-Highest Non-Predatory bookings are categorized (as are all other classes), but the individual offenses under each category are much more serious than those offenses under a similar 
category in a lower class. For example, Class 1-Highest Non-Predatory includes contraband (smuggling contraband into a facility); disobedience (failing/refusing to halt when commanded to do so); disturbance (engaging in or encouraging a group demonstration); escape (possessing escape paraphernalia); mutinous act (recruiting for a gang); sexual (making sexual proposals or threats to another); substance abuse (being intoxicated); substance possession (narcotics trafficking); vandalism (tampering with a security device); and violence (altering any property to make a weapon). Class 2-High categories and examples include: contraband (possessing tattoo equipment); disobedience (failing to comply expeditiously with an instruction from a staff member); mutinous act (partaking in group petitions in any form); sexual (verbal statements that contain amorous expression and/ or sexual language to any staff member); vandalism (willfully ... damaging ... any materials, tools, machinery, and/or any state property); and violence (making verbal threats). 6. In the case of Class 4-Low Moderate bookings, staff have the option of offering the prisoner a oneor two-nighter in lieu of receipt of a booking. A one-nighter is "an administrative loss of institutional privileges for a period of 24 continuous hours and includes the forfeiture of visits, except attorney and RIDOC clergy; telephone, except attorney; furlough, except emergencies approved by Director or designee; recreation; on-grounds classes, school, employment, except at the Warden's/designee's discretion; out-of-cell time, except meals and/or to seek medical care; television and/or radio, except at the Warden's/designee's discretion" (RIDOC, 2009: 2-3). A two-nighter involves the same loss of privileges except for a period of 48 hours. If a staff member chooses the oneor two-nighter option, the charge and disposition are presented to the prisoner and if the prisoner decides to accept it, he would sign a waiver of his right to appear before a Hearing Officer. He would then be given a copy of the waiver and his oneor two-nighter would commence immediately. If he refuses to sign the waiver, he would then be scheduled to go before the Hearing Officer as he would for any other booking.

7. Disciplinary confinement for a Class 1-Highest Predatory booking can last from 31 days to one year; for a Class 1-Highest Non-Predatory, 21 to 30 days; for a Class 2-High, one to 20 days; and for a Class 3-Moderate, three to 15 days. Prisoners found guilty of a Class 4-Low Moderate booking are not eligible for disciplinary confinement, but instead may lose privileges for up to five days. $\subseteq$ 8. No prisoners were interviewed who resided in the Price medium-security building as none of them were in the high-disciplinary category. $\triangleq$

9. Though no such interviews were planned for those without a serious booking during 2008,91 of 150 of these prisoners agreed to an interview (61 percent). $\triangleq$

10. Two staff also brought up the challenges of identifying and dealing with those prisoners with mental health problems who had been involved in misconduct issues. $\subseteq$ 
11. However, there were many prisoners in the HSC who declined participation in either the survey or the interview and it is completely plausible that some of them preferred being housed in segregation than in general population. $\triangleq$ 